European journal of American studies

Special Issue: Sound and Vision: Intermediality and American Music

\title{
Introduction. Sound and Vision: Intermediality and American Music
}

Frank Mehring and Eric Redling

\section{OpenEdition}

\section{Journals}

Electronic version

URL: https://journals.openedition.org/ejas/12384

DOI: $10.4000 /$ ejas. 12384

ISSN: 1991-9336

Publisher

European Association for American Studies

Electronic reference

Frank Mehring and Eric Redling, "Introduction. Sound and Vision: Intermediality and American Music", European journal of American studies [Online], 12-4 | 2017, Online since 28 December 2017, connection on 08 July 2021. URL: http://journals.openedition.org/ejas/12384 ; DOI: https://doi.org/10.4000/ejas. 12384

This text was automatically generated on 8 July 2021.

Creative Commons License 


\title{
Introduction. Sound and Vision: Intermediality and American Music
}

\author{
Frank Mehring and Eric Redling
}

1 The medium of music represents a pioneering force of crossing boundaries on cultural, ethnic, racial, and national levels. Critics such as Wilfried Raussert and Reinhold Wagnleitner argue that music more than any other medium travels easily across borders, language barriers, and creates new cultural contact zones (Raussert 1). With the turn to reception and rise of Cultural Studies, the field of American Studies has expanded its focus on literature and historical narratives to include a broad range of media and practices. As a transdisciplinary field of investigation, the conjuncture between American Studies and media studies has produced new transnational approaches to the functions, attractiveness, and uses of American culture in the age of a digitally connected world. In our special volume we want to put a particular focus on intermediality and American music as an emerging field in transnational American Studies. While intermediality as a theoretical concept has been most widely used with reference to "multiple discourses and modalities of experience and representation, as examined in aesthetic and other humanistic traditions of communication research" (Paech and Schröter, 10, see also Jensen), we are putting our academic spotlight on material mediality (rather than discursive intermediality or institutional intermediality) signaling discursive approaches to media and texts that are interrelated. ${ }^{1}$ In comparison to communication theorists, we, as transnational American Studies scholars, are particularly interested in the interplay between music and other art forms such as literature, painting, photography, video, film, television, graphic novels, and performance cultures. How can we critically analyze, map, and evaluate the nexus between sights, sites, and sounds in different media and genre? How can we trace the effects, exchange, transformations, appropriations, and cultural flows (William Uricchio) as well as processes of (re)mediation (Jay David Bolter, Richard Grusin) of American music? Our volume brings together German scholars and critics in the field of American Studies to investigate the potential of an innovative research agenda with a focus on music in transnational contexts. 
2 Rather than limiting the concept of intermediality to reading literary texts as frames for medial contexts, we understand intermediality as an analytical concept to systematically analyze the manifold interconnections between acoustic and visual media. While critics argue that we live in a world dominated by images, the pictorial turn has contributed to broaden the boundaries of the visual medium affecting film studies, Cultural Studies, literature, and the visual arts. However, while most scholars agree with W. J. T. Mitchell that "all media are mixed media" (211) and are part of a process which, for instance, Jay David Bolter and Richard Grusin identify as remediation, the multifaceted interactions between sound and visual media are often neglected or downplayed. Building on the work of American Studies scholars such as A. Böger, Ch. Decker, W. Fluck, U. Hebel, G. Rippl, and P. Wagner, who investigate the complex dialogues of textual studies with visual studies, we expand current intermedial theoretical approaches by emphasizing the musical dimension in visual media. We want to rethink the nature of sound, the practice of listening, as well as the function and use of music in the interaction with the arts in transnational and transcultural contexts. We thereby hope to refine current discussions on intermediality, remediation, transmedialilty, and multimodality (as found in, for instance, the 2015 Handbook of Intermediality: Literature, Image, Sound, Music edited by G. Rippl). In four original articles, our novel approach to the exploration of sound and vision takes its first cue from American music to investigate the interdependencies, overlappings, and interactions between music and other media (e.g., photography-J. Voelz, graphic novels-L. Etter, film-M. Priewe, popular performing arts-J. Hartmann). The final section will offer excerpts from a visual interview archive created by Wolfgang Lorenz asking: How can biography, African American culture, music and cultural heritage be interlocked successfully with visual culture, i.e. in video or film, or in filmed and archived interviews?

3 In his article "Looking Hip on the Square: Jazz, Cover Art, and the Rise of Creativity" Johannes Voelz explains that in the early 1950s, American jazz entered a phase of artistic blossoming that was accompanied by widespread popularity and unprecedented cultural influence. By the late 1960s, however, this "second jazz age" had come to an end. His article draws on two approaches within cultural sociology to explain the historically specific cultural force of jazz: it follows American sociologist Howard S. Becker's method of reconstructing "art worlds," i.e., the networks of cooperation that include the institutional structures of marketing and distribution. In the jazz art world, the article suggests, sound becomes intermedially embedded in visual culture and textual repertoires. The essay also follows German sociologist Andreas Reckwitz, whose history of creativity allows for interpreting the impact of the jazz art world as a chapter in the rise of a creativity dispositif. In particular, Voelz's essay focuses on the photographic and illustrative work artists like William Claxton and Andy Warhol created for the newly emerging format of the record cover. The visual art of jazz helps account for jazz's ability to transport artistic hipness from the enclave of modernist art into the everyday.

4 Lukas Etter's article "Jazz Between the Lines: Sound Notation, Dances, and Stereotypes in Hergé's Early Tintin Comics" zooms in on the intersection of music and graphic novels. "Jazzy" or not, Etter argues, the close intermedial encounter of jazz and comics, i.e., two medially and semiotically complex forms of expression already by themselves, asks for a general reflection on the nature of sound in combination with visual notes, 
scores, movement, and performance in the comics medium. His essay illuminates how such encounters take shape in specific Francophone Belgian comics of the 1920s and 1930s; it consists of a close reading of musical and sound notation in Hergé's early Aventures de Tintin albums. It departs from the observation that somebody like Hergé, with an oft-reported affinity for jazz, would shy away from making allusion to thriving dancefloors and the presence of African American musicians so central in the "white" Western European discourses of these decades. The essay sheds light on whether this is closely linked to or, conversely, contrasted from colonialist attitudes Hergé propagates especially in his earliest albums-and on how allusions to the jazz age and American music may be read between the panel lines in some Tintin albums all the same.

In "The Power of Conformity: Music, Sound, and Vision in Back to the Future" Marc Priewe turns to the fields of music and film. This essay investigates the aesthetic and political functions of the choice and placement of music in Back to the Future (1985; dir. Robert Zemeckis). After an overview of the movie's cultural contexts, the focus shifts to the interplays between sound and cinematic mise-en-scène, with a particular emphasis on popular music. Priewe argues that the film employs music strategically in order to convey a nostalgic view of American culture and society in the 1950s and 60s by including certain songs and excluding others, as well as by a score (written by Alan Silvestri) that is deeply rooted in the traditions of Hollywood film music. The intermedial use and remediation of music not only amplifies the movie's quasiphilosophical treatment of time and history in intricate ways, it also resonates with the contemporary sense of American exceptionalism.

6 Johanna Hartmann's “Sound, Vision, and Embodied Performativity in Beyoncé Knowles' Visual Album Lemonade (2016)" zooms in on a particularly complex and innovative approach of discussing race and ethnicity within a new audio-visual approach by Beyoncé. Lemonade represents a work of art that exists in various manifestations: as a music album that includes twelve songs, as live performances (including her world tour and her appearance at the Superbowl halftime show), and as a "visual album," an art film that consists of the music video clips for each individual song and visually and auditorily complex "chapters" which feature the poetry by Warsan Shire. This article focuses on the visual album as intermedial artwork that can be described as a soundscape in which the intermedial constellations fulfill a number of functions: Firstly, intermedial references are a means of cohesion that are responsible for the unified character of the visual album. Secondly, intermedial references result in a transcultural signature of the artwork. Thirdly, through intermedial references Beyoncé locates Lemonade within the cultural history of the United States and American music history in particular. Finally, intermediality acquires cultural-critical functions which in particular pertain to race relations and structural forms of discrimination against people of color in contemporary America.

7 In “'Talking 'Bout My Generation': Visual History Interviews-A Practitioner's Report" Wolfgang Lorenz provides a special contribution to our volume emphasizing the field work in creating visual history archives. Lorenz argues that the critical appreciation of videotaped oral history interviews has been hampered by one-dimensional interpretations of the spoken word alone. The addition of the visual dimension in which voice and gestures are necessary constituents to the reading of the material has so far been widely ignored. Unjustly so, because it enriches the discipline with new interpretative approaches that can lead the way to a more human evaluation of 
historical events and personalities, thereby enlivening the dry facts that empirical historical sciences usually provide. The article endeavors to describe what we see when we listen, and how this visual component can enhance informative values.

“"Talking 'Bout My Generation"' discusses these aspects in connection with African American culture and music. The sound bites in this article are part of a series of videotaped oral history interviews with some of the most influential artists, producers and music managers in the history of recorded music. Historically, they cover the period from the 30 s to the 60 s of the last century. Lorenz's article features hitherto unpublished interview material of the soul singer Ben E. King, the Southern musician Jimmy Johnson, the record producer Jerry Wexler, Solomon Burke, the American preacher, singer and one of the founding fathers of 1960 s soul music, and Joel Dorn, the former jazz producer for the iconic Atlantic Records label.

\section{BIBLIOGRAPHY}

Bolter, Jay David and Richard Grusin. Remediation: Understanding New Media. Cambridge: The MIT Press, 1999. Print.

Decker, Christof and Astrid Böger (eds.). Transnational Mediations. Negotiating Popular Culture between Europe and the United States. Heidelberg: Winter, 2015. Print.

Fluck, Winfried. Romance With Amerika. Essays on Culture, Literature, and American Studies. Ed. Laura Bieger and Johannes Völz. Heidelberg: Winter, 2009. Print.

Hebel, Udo J. “'American' Pictures and (Trans-)National Iconographies: Mapping Interpictorial Clusters in American Studies." Journal of Transnational American Studies. 6.1 (2015): 401-431. Print.

Jensen, Klaus Bruhn. "Intermediality." The International Encyclopedia of Communication Theory and Philosophy. 1-12. onlinelibrary.wiley.com/ Accessed 28. Feb. 2018. Web.

Mitchell, W. J. T. What Do Pictures Want? The Lives and Loves of Images. Chicago: The Chicago UP, 2005. Print.

Paech, J., and Schröter, J., eds. Intermedialität-Analog /Digital: Theorien, Methoden, Analysen. Paderborn: Wilhelm Fink Verlag, 2007. Print.

Raussert, Wilfried, and James Miller Jones, eds. Travelling Sounds: Music, Migration, and Identity in the U.S. and Beyond. Berlin: LIT, 2008. Print.

Rippl, Gabriele. “Introduction.” Handbook of Intermediality: Literature - Image - Sound - Music. Ed. Gabriele Rippl. Berlin: De Gruyter, 2015. 1-31. Print.

Uricchio, William. "Things to Come in the American Studies-Media Studies Relationship." American Studies Today: New Research Agendas. Ed. Winfried Fluck, Erik Redling, Sabine Sielke, and Hubert Zapf. Heidelberg: Winter, 2014. 363-382. Print.

Wagnleitner, Reinhold. "Jazz-The Classical Music of Globalization.” Travelling Sounds: Music, Migration, and Identity in the U.S. and Beyond. Ed. Wilfried Raussert and James Miller Jones. Berlin: LIT, 2008. 23-60. Print. 


\section{NOTES}

1. Klaus Bruhn Jensen describes this interrelation as "material means of interaction" (5). He explains that the term denotes "communication through several discourses at once, including through combinations of different sensory modalities of interaction" (5).

\section{AUTHORS}

\section{FRANK MEHRING}

Frank Mehring is chair and professor of American Studies at Radboud University, Nijmegen. He teaches twentieth- and twenty-first century visual culture and music. His publications include Sphere Melodies (2003) on Charles Ives and John Cage, Soundtrack van de Bevrijding (2015) on WWII sheet music and The Mexico Diary: Winold Reiss Between Vogue Mexico and the Harlem Renaissance (2016). In 2012, he received from the European Association for American Studies the biennial Rob Kroes Award for his monograph The Democratic Gap (2014). He organized the first international symposium on Winold Reiss in Berlin (2011) and co- curated exhibitions on Winold Reiss, the Marshall Plan, and Liberation Songs in New York, Nijmegen and The Hague.

\section{ERIC REDLING}

Erik Redling is Professor of American Literature and founding Director of the Muhlenberg Center for American Studies at Martin Luther University Halle-Wittenberg. He is the author of "Speaking of Dialect": Translating Charles W. Chesnutt's Conjure Tales into Postmodern Systems of Signification (2006) and Translating Jazz Into Poetry: From Mimesis to Metaphor (2017). He has co-edited (with Winfried Fluck, Sabine Sielke, and Hubert Zapf) the volume American Studies Today: Recent Developments and Future Perspectives (2015) and edited the essay collection Traveling Traditions: Nineteenth-Century Negotiations of Cultural Concepts in Transatlantic Intellectual Networks (2016). He has published in the fields of literary theory, cognitive theories, intermediality and translation, dialect literature, jazz poetry, and the graphic novel. His current book project explores the linguistic-aesthetic history of vernacular cultures in nineteenth- and twentieth-century America. 